\title{
Sizing Technique of Water and Salt-water Solution Droplets: NGB (Dye)-gelatin Film Method
}

by

Ken-ichi USHIKI, Masafumi IMOTO, Seiji HANATANI and Koichi IINOYA

(Dept. of Chem. Eng., Kyoto University)

A Naphthol Green B (NGB) dyestuff gelatin film, coated on a slide glass, can be used for determining the size distributions of water or salt-water solution droplets. The stain sizes that remained after the evaporation of droplets that impacted a slide glass, are calibrated by using the solid particle tracer method, the silicone oil film method and the two-stages cascade impactor. The following results are obtained experimentally: 1) The calibration results using these three different methods agree well with each other, and the diameter of the droplets are 0.54 times the diameter of the stains, on the average; 2) The value 0.54 is almost independent of the droplet diameters, the concentration of NGB dyestuff and the velocity of the approaching droplet velocity within the experiment range; 3) The value of the ratio for $4 \%$ salt-water solution droplets is almost the same as that of water droplets; and 4) The best composition of gelatin sol is $10 \mathrm{ml}$ of distilled water, $0.5 \mathrm{~g}$ of NGB dyestuff and $0.6 \mathrm{~g}$ of dried gelatine.

\section{研 究 報 告}

\section{鳴き砂の発音機構について*}

Generating Mechanism of Harmonic Sound from Singing Sand

\section{日 高 重 助** 三 輪 茂 雄** Jusuke HIDAKA Shigeo MIWA}

\section{1. 緒 言}

砂の堆積層を適当な方法で圧縮すると明りょらな楽音 を発生する鳴き砂***は Singing sand あるいは Musical sand などと呼ばれ世界中の多くの場所で見ることがで きる゙)。したがってこの興味深い現象についての研究は 古くからなされており, その粒子特性および発音機構に 関して約40～50件以上にの涪る報告8) があるが，まだ十 分納得できる発音機構の説明はない。

鳴き砂は適当な容器に充てんしてその堆積層に貫入棒 を押し込むと容易に発音する。本報ではこの方法により 発音させ鳴き砂粒子層が音を発生している状態の詳細な 観察および粉体層の貫入現象の解析にもとづいて得られ

昭和55年12月18日受付

*第18回粉体に関する討論会にて講演（1980.11 豊橋）

**同志社大学工学部化学工学科（テ602 京都市上京区烏丸今出川東入ル） TE L $075-251-3847$
る鳴き砂粒子層の摩擦角特性と発生音の性質などについ て調べ鳴き砂の発音機構を検討した。すなわち貫入棒に より鳴さ砂を発音させた時の発音現象は粒子同士の摩擦 による音や粉体層の圧縮による層内の空気の噴出にもと づく空気力学的な音あるいは粒子層の振動による放射音 ではなく, 鳴き砂粒子層が顕著に示す Stick-slip 現象に もとづいて発生する周期的な貫入抵抗力が貫入棒に作用 し貫入棒の縦振動を励振することにより放射される音で あることを報告する。

鳴さ砂粒子の粒子特性について次の特徵が指摘されて

***“鳴り砂”と呼ばれることもあるが “鳴る”現象は注目する物 体の固有振動が励振されて発音している状態をさす場合が多 く, 鳴き砂は後述する発音機構からも明らかなよらに摩擦音の らちの鳴き音を発生しているために“鳴き砂”が適当である。

\section{2. 鳴き砂について}




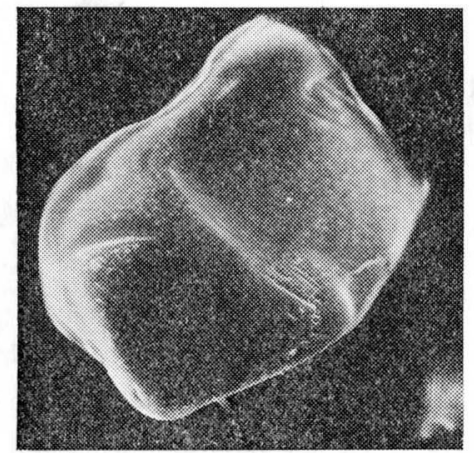

Fig. 1 A representative particle of singing sand.

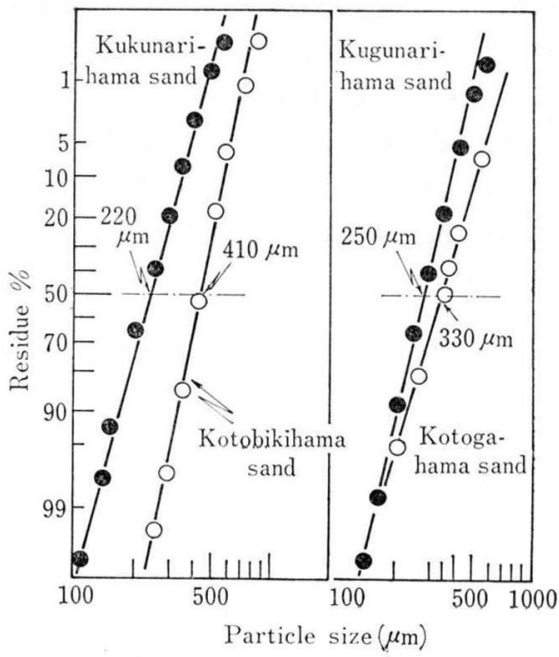

Fig. 2 Particle size distribution of the singing sands.

いる4)。(1)主に石英粒子から成り $90 \%$ 以上を占めてい る。(2)粒度分布の分布幅が非常にせまい。(3)粒子形状は やや丸みをおび，特に粒子は鋭いエッジを持たず扁平状 や針状の粒子を含をない。(3)一般の砂状粒子層にくらべ 静止摩擦係数が大きい。（静止摩擦角 $\phi_{s}$ が $36^{\circ} \sim 38^{\circ}$ 以 上を示すे)

Fig. 1, 2 に本実験で用いた鳴き砂試料の粒子外観 写 真, 粒度分布を示し, Table 1 に静止摩擦角を示した。 これらの特徵は非常に長い間の風の力や海の波の力によ って形成された鳴さ砂に見られる特徵であるが，しかし これらの特徵のすべてが音を発生するための必要条件と は考学られない。たと壳石英粒子 $90 \%$ 以上を含むが音 を発生しない海岸砂がある10)。また種々の粒度の鳴き砂 試料を混合して粒度分布を広くしても音を発生する。上 記(1)(2)(3)の特徽をすべて合せ持つガラスビーズやオタワ サンドは通常の状態では音を発生しない。しかしガラス ビーズの場合，粒子表面を良く洗浄した後粒子層の運動 を適当に拘束するような容器に充てんして貫入棒を押し
Table 1 Angle of internal friction of the singing sand

\begin{tabular}{l|c}
\hline \multicolumn{1}{c|}{ Sample } & Angle of internal friction \\
\hline Kotobikihama & $38.6^{\circ}$ \\
Kotogahama & $37.5^{\circ}$ \\
Kukunarihama & $36.7^{\circ}$ \\
Kugunarihama & $36.3^{\circ}$ \\
\hline
\end{tabular}

Table 2 Co-ordination number and compressibility of the singing sand.

- Compressibility (with powder Tester)

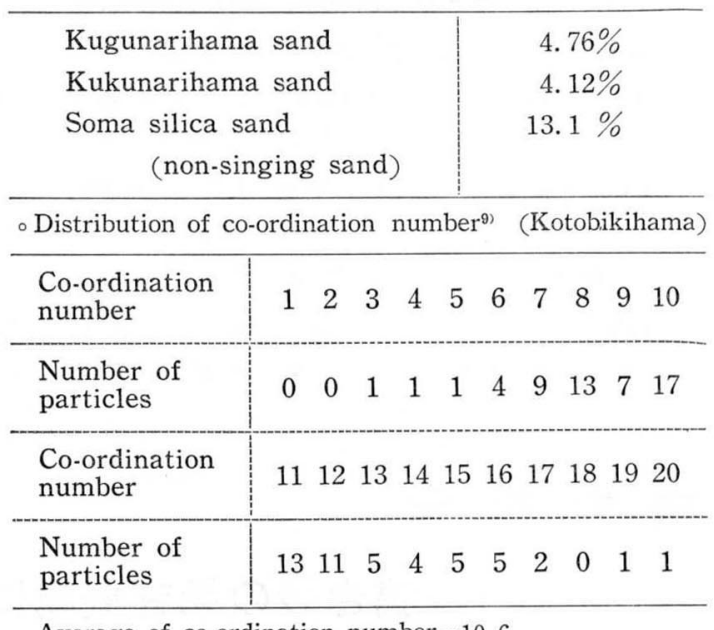

Average of co-ordination number $=10.6$

込むと調和音を発生する。これは容器壁からの受働抵抗 力を作用させてガラスビーズの静止摩擦力が大きくなる 状態にした効果によるものである。したがってこの現象 や鳴き砂粒子の特徵(4)は鳴き砂の発音機構を考学るらえ で粒子層の摩擦角特性の検討が重要であることを示唆し ている。

鳴き砂の発音機構についてもすでに多くの報告があ る8)。それぞれの説明に微妙な差があるが，これらは(1) 粒子間摩擦説, (2)空気クッション説, (3)空気噴出説, (4) 粒子層振動説に大別できる。

Wilson ${ }^{3)}$ は「粒子径のそろった無数の清浄な砂 粒子 相互の摩擦」が原因であるとして粒子間摩擦説を提出し た。しかし一般に単一粒子相互の摩擦により発生する音 の音圧はきわめて低いこと，またその周波数は非常に高 いと推察されること扰よびランダムな場所から発生する 摩擦音は純音に近い正弦波状の音波を形成しないと考觉 られることなどの疑問がある。これに対して Bolton ${ }^{2)}$ は空気クッション説を提出しているが粒子層内で砂粒子 が弾性的に振動することに対する力学的説明がない。栗 原 ${ }^{7)}$ は「粒子層が摩擦すると，それにより粒子間空隙に 


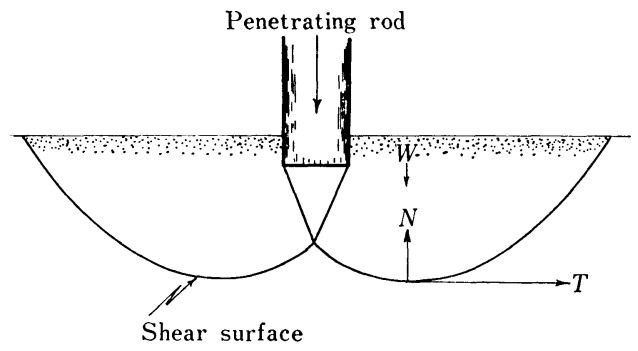

Fig. 3 Vertical force which acts on the shear surface resulting from a vertical push into a packed bed of particles.

存在する空気が圧縮されて櫴出し空気の疎密波を構成す る」と空気噴出説を提出した。しかし Table 2 に示す ように鳴き砂粒子は配位数が大きく, 圧縮度が非常に小 さい粉体であること，さらに粉体層の圧縮流動過程を力 学的に考察すると粉体層に力が作用した瞬間にわずかに 粒子層が圧縮される過程* が，存在するが非常に短かい 時間に達成されその後は膨張する過程であることなどか らこの説明にも疑問が残る。一方 Bagnold ${ }^{11)}$ は砂層に 対する詳細な力学的考察を行ない粉体層が圧縮される時 層内に発生するすべう面上の粒子層の振動により音が発 生することを報告した。すなわち Fig. 3 亿示すように すべりが発生する瞬間の垂直方向の力 $N$ はすべり面上粒 子層の自重よりも大きくなり粉体層を上方に移動させる がその過程で粉体層が膨張するためにNは急激に減少 し，その結果としてすべり面上の粒子層が振動し音を放 射すると考えた。粉体層の力学的考察の面から興味深い が，音の発生の点からはすべり面上の 粒子層が 200〜 $1000 \mathrm{~Hz}$ の高い周波数で共振することが困難であろうと 考える。

現在までに提出されている発音機構に関寸る説明は以 上であるが，まだいずれも基本的な点での疑問を残して いる。したがって発音機構の解明に際して，まずはじめ にこれらの説明の妥当性を検討しておくことが必要であ る。

\section{3. 鳴き砂粒子層から発生する音の音源}

前説で述べた発音機構の諸説はいずれも鳴き砂の音が 粒子の摩擦振動, 粒子層空隚内の空気噴出, 粒子層の振 動に起因して粒子風表面から直接放射されていることを 示している。またこれらいずれの説明においても粒子層 内および粒子層表面近傍の空気の存在は必要不可欠であ

*Fig.12 に示す貫入板 $\mathrm{AA}^{\prime}$ 面下に三角形状で示される剛性域 が形成する時压縮される。この用性域は砂状粒子層では瞬時に 形成される。

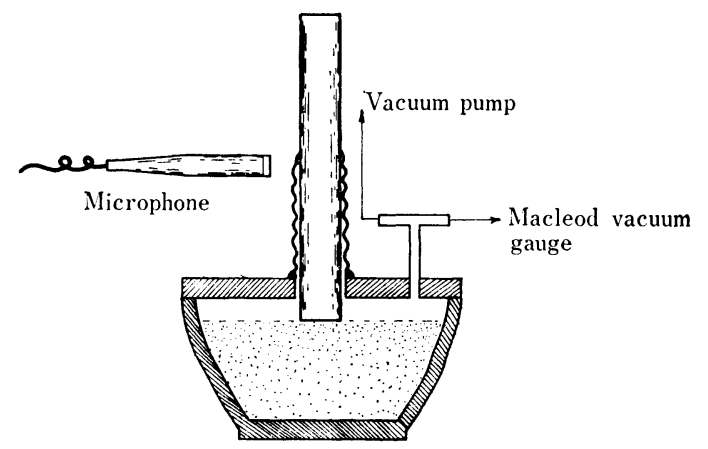

Fig. 4 Experimental apparatus for measurement of sound pressure from the singing Sand in a vacuum.

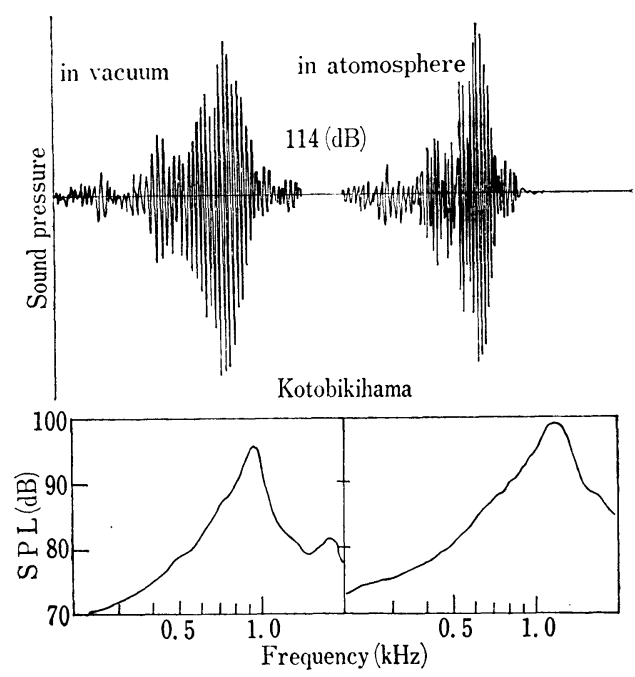

Fig. 5 Sound pressure waveform and frequency spectrum from the singing sand in a vacuum.

ク，もし粒子層内およびその表面近傍が真空状態にあっ たならば音は発生しないことになる。そこで Fig. 4 に 示す装置により鳴き砂粒子堆積層の部分のみを真空状態 にして貫入棒を鳴き砂粒子層に押し込み容器系外に音が 放射されるかどらかの測定を行ない前節の発音機構に関 する諸説を検討した。実験装置は鳴き砂を充てんした乳 鉢の上端面に厚さ $15 \mathrm{~mm}$ の透明アクリル板を接着し, アクリル板上に立てた T字状ガラス管の一方を真空ポン プにまた他方を真空度を測定するためのマクレオードゲ ージに接続した。粉体層を含む乳鉢内部の真空度が 0.1 $\mathrm{mmHg}$ に到達した時, 針金入りビニール製フレキシブ ルホースに接着して中央部に設置した木製の貫入棒を鳴 き砂粒子層表面から手で押し込んで発音させた。その時 乳鉢系外に放射される音をコンデンサーマイクロホンで 


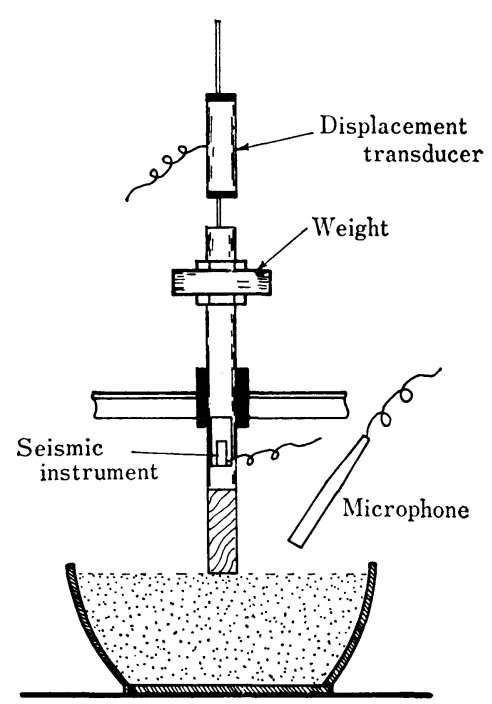

Fig. 6 Experimental apparatus for measurement of the nature of sound.

検出し, ウェーブメモリーに記憶させた後音圧波形の記 録および周波数解析を行なった。

Fig. 5 は鳴き砂粒子層の部分を真空状態にして発音 させた場合と粒子層を大気中に開放して発音させた場合 の音圧波形とその周波数スペクトルを比較したものであ る。貫入棒を手で押し込んで発音させるために発音条件 （とくに貫入速度）を同じにすることが不可能であり発 生音の性質を厳密に比較できないが，粉体層部分を真空 下において貫入棒を貫入させても容器系外には大気に開 放した場合とほとんど同じ高さの音圧でしかも良く似た 周波数スペクトルを持つ音が放射されることが分る。こ の結果は前節で示した発音機構に関する諸説が鳴き砂か らの音の発生を十分説明していないことおよび鳴き砂の 音は粉体層から直接放射されているのではなく貫入棒か ら放射されている可能性を示唆しており，以下では鳴き 砂が発音している状態をさらに詳しく観察し発音機構を 検討する。

\section{4. 実験装置および方法}

[鳴き砂から発生する音の測定〕鳴き砂を発音させる 条件と発生音の性質との関係を得るために用いた発音試 験装置を Fig. 6 に示す。乳鉢に一定量の試料を充てん した後，貫入棒を試料表面から静かに落下させると貫入 棒はその自重により粉体層へ貫入する。貫入棒の重量は 貫入棒上部に荷重板を取り付けることで变えることがで き，それにより貫入速度が变化する。貫入時に粉体層か

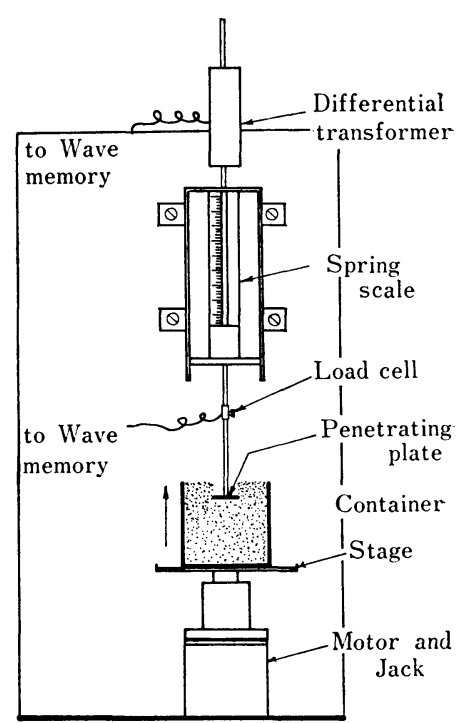

Fig. 7 Experimental apparatus for the measurement of friction characteristic of a packed bed of particles.

ら発生する音はコンデンサーマイクロホンにより検出し ウェーブメモリーに記憶させた後，くり返し再生して音 圧の測定, 音圧波形の記録および周波数解析を行なっ た。また貫入棒の変位および貫入棒の加速度振動は歪み ゲージ式変位計および圧電型加速度ピックアップにより 検出し音圧波形とともに同時にウェーブメモリーに記憶 させ記録した。

な戚粉体層が貫入棒より受ける圧縮力 $P$ は貫入棒の加 速度波形から次式により算出した。

$$
P=m(g-\alpha)
$$

ここで, $m$; 貫入棒の質量, $g$; 重力加速度, $\alpha$; 貫入 棒の振動加速度である。

〔粉体屬の摩擦特性の測定】 鳴き砂の発音機構を検討 するためには粉体層の摩擦角特性, とくに静止摩 擦角 $\phi_{s}$ と動摩擦角 $\phi_{d}$ を知ることが必要である。Fig. 7 は その測定に用いた装置であり，鳴き砂を発音させる場合 と同様に粉体層へ貫入板を貫入させて粉体層の摩擦特性 を知ることができる。以下ではこれを貫入試験と呼ぶこ とにする。試料を充てんした容器を一定速度で上昇する 試料台に載せて上昇させると貫入板に接し，押し上げ式 バネ科りにより荷重がかかるので粉体層の強度に応じて 貫入板が粉体層へ貫入する。貫入板の貫入過程における 粉体層表面からの貫入深さ（变位）とその時貫入板にか かる荷重の刻々の変化をロードセルと差動变圧器により 
Table 3 Particle size and angular property of silica sand.

\begin{tabular}{c|c|c}
\hline sample & $\begin{array}{c}\text { particle size } \\
{[\mu \mathrm{m}]}\end{array}$ & angle of repose \\
\hline Silica sand (A) & 525 & $37^{\circ}$ \\
Silica sand (B) & 525 & $38^{\circ}$ \\
Silica sand (C) & 525 & $35^{\circ}$ \\
Silica sand (D) & 525 & $34^{\circ}$ \\
\hline
\end{tabular}

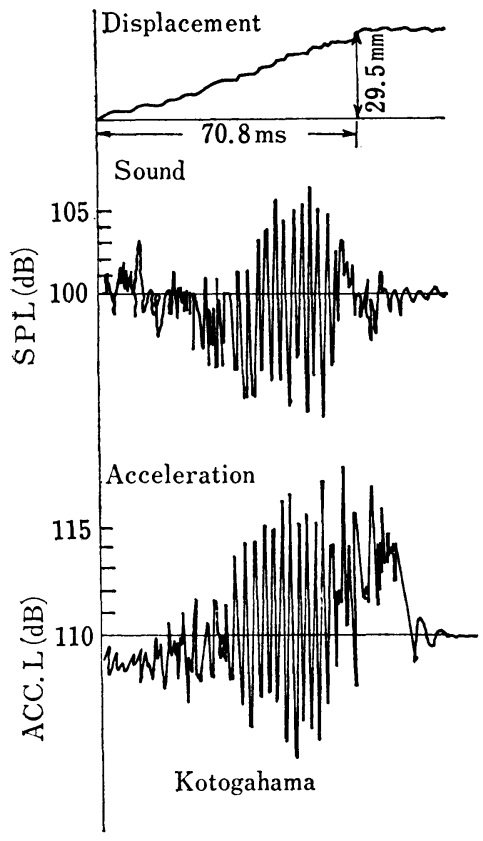

Fig. 8 Waveform of sound pressure and displacement, acceleration of the penetrating rod.

検出し，増幅器を経てレコーダーに記録した。用いた貫 入板直径は $10^{\phi}, 20^{\phi}$ ，貫入容器の直径は $146^{\phi}$ である。 また試料台の上昇速度は $1.16[\mathrm{~mm} / \mathrm{s}]$ とした。

[試料] 鳴き砂試料は琴引浜, 十八鳴浜, 九九鳴浜, 琴ヶ浜から採取したものでその粒子特性はすでに Fig.

1，2，Table 1，2 に示した*。ほかに鳴き砂と同質の 市販のケイ砂を用いた。その特性を Table 3 と示す。

* 琴引浜(京都府竹野郡網野町掛津)

琴ヶ浜(島根県仁万郡馬路)

十八鳴浜(Kugunarihama. 宮城県気仙沼市大島大初平) 九九鳴浜(Kukunarihama. 宮城県本吉郡唐桑町西舞根)

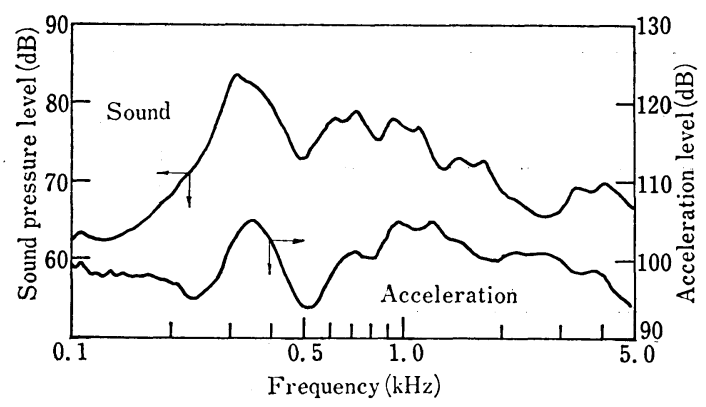

Fig. 9 Frequency spectra of sound pressure and acceleration of the penetrating rod.

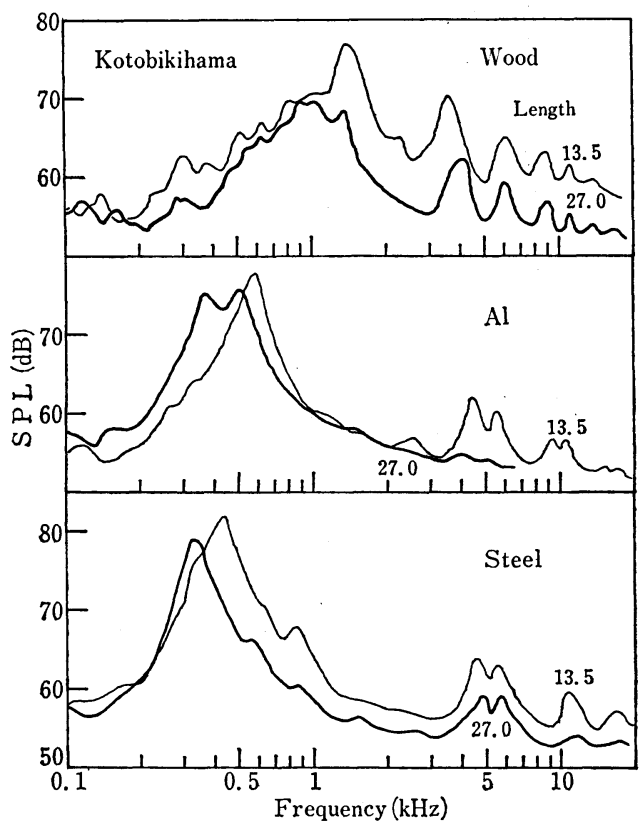

Dia. of rod $25^{\circ}$

Fig. 10 Relationship of the frequency spectrum of the sound from the singing sand and the fundamental frequency of the penetrating rod.

\section{5. 鳴き砂からの発生音の測定結果と考察}

\section{1 貫入棒からの音の放射機構}

貫入棒の振動加速度と発生音波の関係 : 鳴き砂発音時 の変位, 音圧, 振動加速度の各波形は貫入条件により变 化するが, [Fig.8 は鳴き砂が音を発生する時の各波形 を同時測定した例である。变位曲線の勾配から刻々の貫 入速度および平均貫入速度を得ることができる。貫入棒 の貫入初期において音王波形，加速度振動波形はともに 不規則な波形を示すが，貫入が進み，貫入速度が大きく なった時急に正弦波状の波形を示して高い音圧で調和音 
Table 4 Frequency of longitudinal vibration of the penetrating rod.

\begin{tabular}{|c|c|c|c|c|}
\hline Material & $\begin{array}{c}\text { Length } \\
L \\
{[\mathrm{~m}]}\end{array}$ & $\begin{array}{l}\text { Fundamental } \\
\text { frequency } \\
f[\mathrm{kHz}]\end{array}$ & $\begin{array}{l}\text { Density } \\
\rho \\
{\left[\mathrm{kg} / \mathrm{m}^{3}\right]}\end{array}$ & $\begin{array}{l}\text { Young } \\
\text { modulus } \\
E\left[\mathrm{~N} / \mathrm{m}^{2}\right]\end{array}$ \\
\hline Wood & $0.135, \quad 0.27$ & $9.35, \quad 18.70$ & $7.8 \times 10^{3}$ & $2 \times 10^{11}$ \\
\hline Aluminum & $0.135,0.27$ & $9.46, \quad 18.92$ & $2.7 \times 10^{3}$ & $7.05 \times 10^{10}$ \\
\hline Steel & $0.135,0.27$ & $9.83,19.66$ & $0.46 \times 10^{3}$ & ${ }^{3} 1.3 \times 10^{10}$ \\
\hline
\end{tabular}

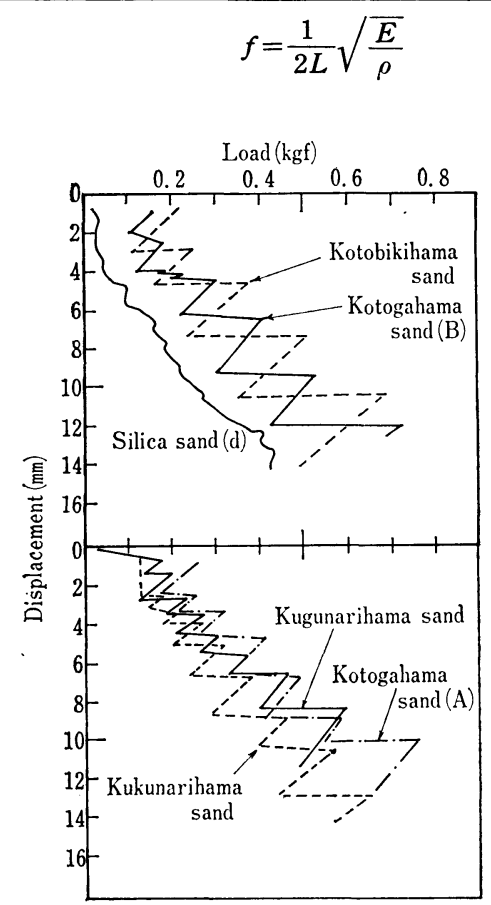

Fig. 11 Penetration characteristic curves of the singing sands.

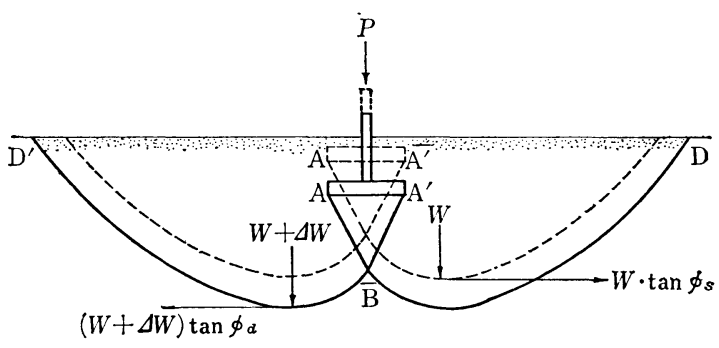

Fig. 12 Penetration process of the penetrater into a powder bed.

を発生する。ここで貫入棒の縦方向の振動加速度波形と 音王波形を比較すると二つの波形は非常に良く以てお ク，Fig.9は二つの波形の周波数スペクトルを示してい る。二つの周波数スペクトルに护ける各ピークの周波数 はほとんど一致していることが分る。

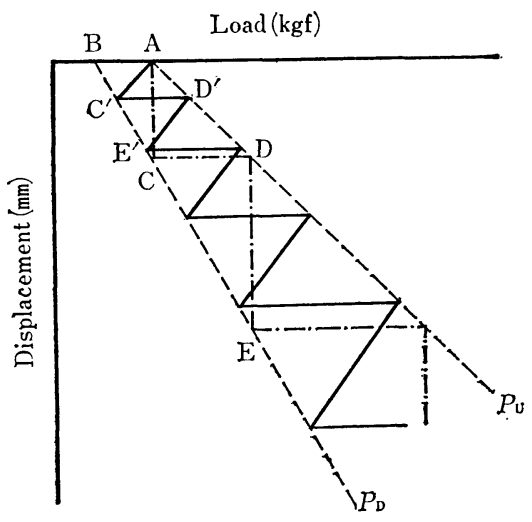

Fig. 13 Penetration characteristic curve.

貫入棒の固有振動数と発生音の性質 : Fig. 10 は貫入 棒の材質とその長さを変えて貫入棒の縦固有振動数と発 生音の周波数スペクトルとの関係を示している。貫入 棒として用いた材料, 寸法およびその稆固有振動数を Table 4 に示した。発生する音の性質は貫入棒の材質や 長さによって変化し，その傾向は貫入棒の䋊固有振動数 が低下するにつれて発生音波の周波数も低下することが 分る。

これらの結果と 3 節の結果から鳴き砂粒子層から発生 する音は粒子層から直接放射されているのではなく粒子 層が貫入棒の貫入により圧縮流動する過程で貫入棒に粒 子層から周期的な力が作用し, 貫入棒の縦振動を励振し て放射しているものと推察される。

\section{2 粉体層の摩擦角特性亡発生音の性質}

貫入棒の縦振動を励振するに必要な周期的な力が発生 する原因は粉体層の摩擦特性によるものと考只られる。 そこで貫入棒が貫入する時の粉体層の摩擦角特性および 摩擦角特性と発生音の性質について検討する。

鳴き砂粒子の摩擦角特性 : 貫入試験により得られた各 試料の荷重と変位の関係を示す曲線（貫入過程曲線と呼 ぶ）を Fig.11 に示す。この貫入過程曲線から次の解 析に上り粉体層の静止摩擦角と動摩擦角に関する知見が 得られる ${ }^{5}$ 。

Fig. 12 に示寸粉体層の $\mathrm{AA}^{\prime}$ （破線）面に荷重が加え られるとその荷重が粉体層の極限支持力 $P_{u}$ に達するま で貫入板は静止しているが $P_{u}$ に達すると同時に粉体層 はすべりを生じて急激に貫入し実線で示した $\mathrm{AA}^{\prime}$ 面で 停止する。この停止する位置は簡単なためスベリ線上の 水平方向の力の関係で示すと次式に示す力の平衡により 決まる。

$$
\begin{aligned}
W \cdot \tan \phi_{s} & =(W+\Delta W) \cdot \tan \left(\phi_{s}-\Delta \phi\right) \\
& =(W+\Delta W) \cdot \tan \phi_{d}
\end{aligned}
$$


ここで $W$ : すべり面上の粉体層の重量, $\phi_{s}$ : 静止摩擦 角, $\phi_{d}$ : 動摩擦角, $\Delta W$ : 貫入によって增加したすべり 面上の粉体層の重量增加, $\Delta \phi=\phi_{s}-\phi_{d}$ を示す。停止し た貫入板は試料台が上昇して荷重が増加するのでまたそ の深さに护ける極限支持力に達するとすべりが生じ急激 に貫入する。貫入板はこの過程をくり返して粉体層へ貫 入する。したがって粉体層から貫入板に作用する力につ いても(2试と同じ関係があるので貫入過程を Fig. 13 に 示す貫入過程曲線上で考える。すなわち粉体層はA点で 示される極限支持力に等しい力が貫入板に加えられると すべりを生じ，すべりが生じると同時に粉体層の静止摩 擦角 $\phi_{s}$ は $\phi_{s}$ より $\Delta \dot{\phi}$ だけ小さい $\phi_{d}$ に移るので支持 力は急激に低下して貫入板はすべり面上の粉体層の重量 增加により最初の力と釣り合う C 点まで貫入して停止す る。しかし本実験では荷重をかけるためにバネ科りを用 いているので貫入板が粉体層へ貫入するとバネが縮むた めに荷重が減少するのでバネ定数と変位で決るる $\mathrm{C}^{\prime}$ 点 で停止する。したがって粉体層の各深さに拈ける粉体層 の極限支持力を摩擦角をパラメーターとして得ることに より䐝入試験結果から粉体層の静止摩擦角と動摩擦角を 推測できる。各深さに拈ける粉体層の極限支持力の推定 は貫入深さが比較的浅いので次式で示される Meyerhoff の式を用いた1)。（ただし実験に用いた試料は非付着性 の試料のため付着力に関係する項は省略した。)

$$
P_{u}=\rho_{B} \cdot H \cdot N_{q} \cdot d_{q}+0.6 \cdot \rho_{B} \cdot\left(D_{p} / 2\right) \cdot N_{r} \cdot d_{r}
$$

ここで

$$
\begin{gathered}
N_{q}=\frac{1}{1-\sin \phi_{s}} \cdot \exp \left\{\left(\frac{3 \pi}{2}-\phi_{s}\right) \tan \phi_{s}\right\} \\
N_{r} \doteqdot\left(N_{q}-1\right) \tan \left(1.4 \phi_{s}\right), \quad d_{r}=1+0.6\left(H / D_{p}\right)
\end{gathered}
$$

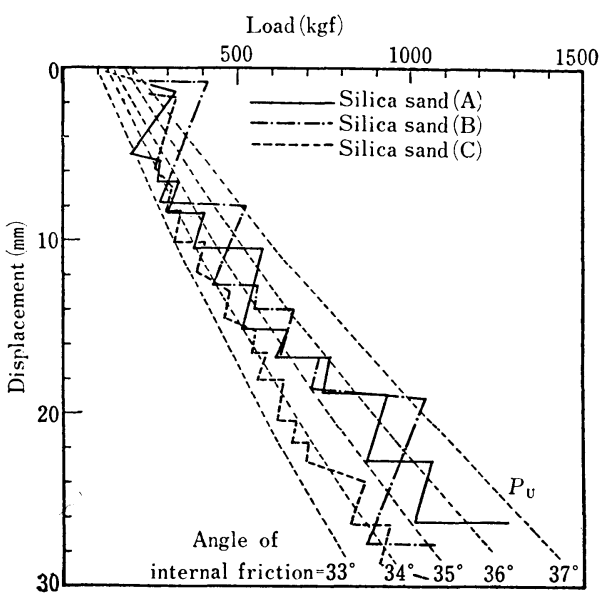

Fig. 14 Penetration characteristic curves of silica sands.

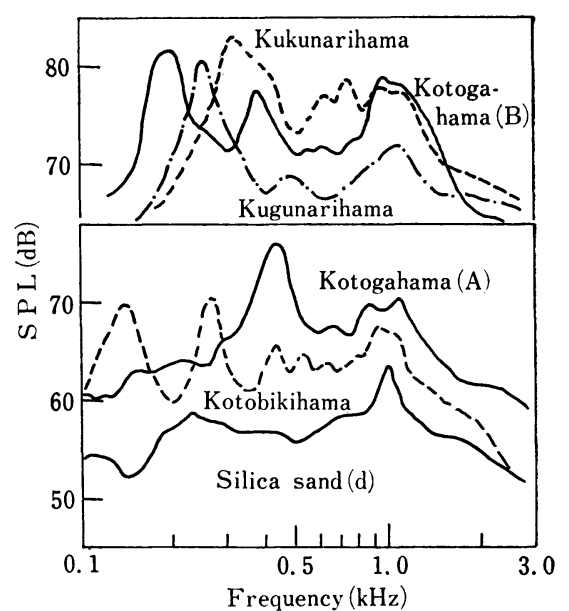

Dia. of the rod 29 \%

Fig. 15 Frequency spectra of the sound from the singing sands.

$d_{q}=1+0.2\left(H / D_{p}\right)$

$\rho_{B}$ : かさ密度, $H$ : 貫入深さ, $D_{p}$ : 貫入板直径を示す。

Fig. 14 はその安息角（箱傾斜法による）が $37^{\circ}, 38^{\circ}$, $35^{\circ}$ の市販のケイ砂(A)(B)(C)による測定例であり図中の点 線は(3)式により計算した粉体層の支持力曲線である。各 すべり開始点を結ぶ支持力曲線の摩擦角から $\phi_{s}$, 各す ベり停止点を結ぶ支持力曲線から $\phi_{d}$ を推定できる。た とえばケイ砂(B)の昜合 Fig. 14 から $\phi_{s} \doteqdot 37.5^{\circ}, \phi_{d} \doteqdot$ $34^{\circ}, \Delta \phi \doteqdot 3.5^{\circ}$ を得る。

Fig. 11 の鳴き砂試料の貫入過程曲線から琴引浜, 琴 ケ浜(B)の鳴き砂の $\phi_{s}, \phi_{d}$ は十八鳴浜, 九九鳴浜のそれ よりも大きく, 静摩擦の状態から動摩擦に移るとその摩 擦係数が急激に低下する性質を持っていることが分る。 したがって鳴き砂の貝入曲線は規則的な階段状の曲線を 示すのが特徵で Stick-Slip 運動を示す。それに対して 市販のケイ砂(d)は $\phi_{s}, \Delta \phi$ とも相当小さく， とくに $\Delta \phi$ の值が小さいために明瞭な階段型の曲線を示さないで不 規則な曲線となる。

摩擦角特性と発生音の性質 : Fig. 15 は Fig.11 に示 した摩擦角特性を持つ各鳴さ砂試料を同一条件で発音さ せた場合の発生音の周波数スペクトルを比較したもので ある。明りょらな Stick-Slip 摩擦現象を示さない市販 のケイ砂(d)は人間の耳で聞学とるのが困難な程の低い音 圧の音しか発生せず, 発生音波の周波数は鳴さ砂にくら べ非常に高い。それに対して明りょらな Stick-Slip 摩 擦を示す鳴き砂はいずれもケイ砂より 10〜20 dB 程度の 高い音圧で正弦波状の音圧波形を持つ調和音を発生し， 


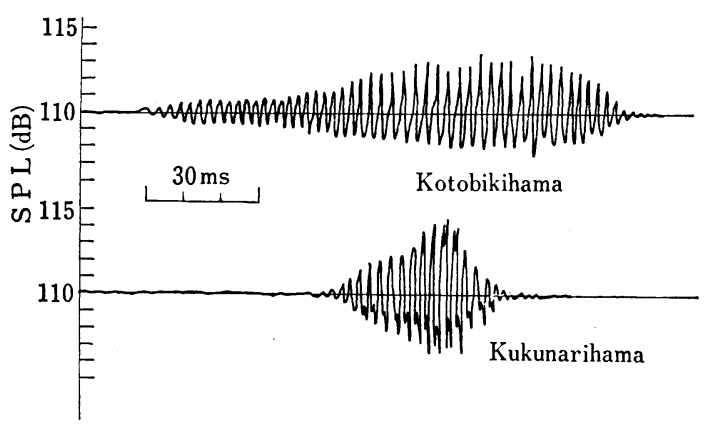

Fig. 16 Waveforms of sound pressure of the singing sands from kotobbikihama and Kukunarihama.

周波数が低く人間の耳にはっきりと聞くことができる。 鳴き砂粒子層の静止摩擦角 $\phi_{s}$ は発生音の音圧に関係 し， $\phi_{s}$ が大きくなるにつれ音圧が低下する 傾 向を示 す。 そこで $\phi_{s}$ の大きい琴引浜砂と $\phi_{s}$ の小さい九九鳴 浜砂の音王波形を比較すると音の発生状沉ぶ異なること が分る (Fig. 16)。すなわち $\phi_{s}, \Delta \phi$ が大きい琴引浜砂 は貫入初期から比較的低周波数の音を発生し貫入棒が停 止する寸前に比較的高い周波数の音を発生するのにくら べ， $\phi_{s}, \Delta \phi$ の小さい九九鳴浜の鳴き砂は貫入初期の低 周波音を発生せず，貫入棒は大きな貫入速度で貫入して 停止する寸前に非常に高い音圧で高い周波数の音を発生 する。一般には $\phi_{s}, \Delta \phi$ の値が大きい鳴き砂が広い範囲 の条件で音を発生しすぐれた鳴き砂といえるが， $\phi_{s}$, $\Delta \phi$ が小さい場合でも貫入速度が增大すると見掛けの $\phi_{s}, \Delta \phi$ が大きくなることや貫入変位とともに粉体層の 摩擦力が増大するために音を発生する。

発生音の周波数は上述のように $\phi_{s}, \Delta \phi$ に依存し, $\phi_{s} ， \Delta \phi$ が大きくなるにつれ周波数が低下する。またこ の周波数は試料の粒子径には関係しない。これは琴ケ浜 (A)とその粒子表面を洗浄して $\phi_{s}, \Delta \phi$ を大きくした琴ヶ 浜(B)の周波数スペクトルを比較すると明らかである。ま たこの結果および琴引浜, 琴ヶ浜(A)，九九鳴浜の各試料 の周波数スペクトルを比較すると最大音圧を示すピーク の周波数が粒子径に関係しないことが分る。この発生音 の周波数と $\phi_{s}, \Delta \phi$ の関係を貫入過程曲線上で考学ると 貫入過程曲線に現われる階段の数すなわちすべりの回数 が減少するにつれ発生音波の周波数が低下することにな る。

これらの結果から鳴き砂粒子層が示す Stick-Slip 摩 擦現象が音を発生する原因であり，したがって発生音の 性質は粒子層の $\phi_{s}, \phi_{d}, \Delta \phi$ の影響を受けることが分 る。

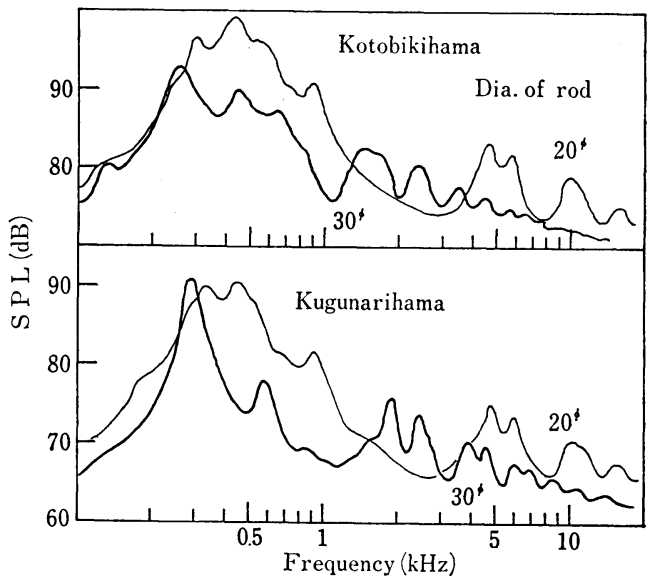

Fig. 17 Influence of diameter of the penetrating rod on the nature of the sound.
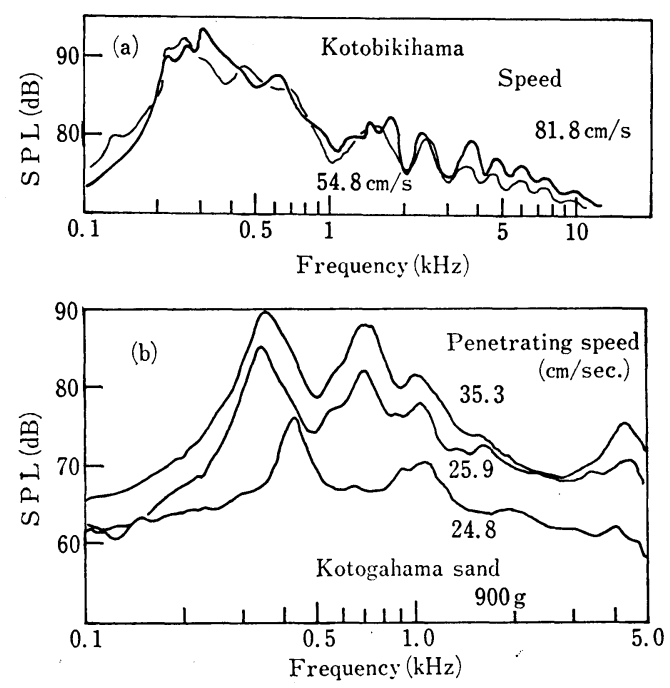

Fig. 18 Influence of speed of the penetrating rod on the nature of the sound.

以上の結果と 5.1 節の結果とから鳴き砂の発音機構は 次のように考えられる。鳴き砂粒子層に貫入棒を貫入さ せると粒子層が Stick-Slip 摩擦を生じるために貫入棒 には粒子層から間欠的な力（周期的な力）が貫入抵抗力 として作用するために貫入棒はその結果として間欠的な 運動をしながら粒子層に貫入する。貫入棒の貫入過程で この間欠的な貫入抵抗力が連続パルス状に貫入棒へ作用 して貫入棒の縦振動を励振することにより音を放射する ものと考える。なお貫入棒自体の間欠的な運動が音を放 射する可能性が考えられるが，材質の異なる同じ寸法の 貫入棒を同一条件で貫入させた時に放射される音の性質 


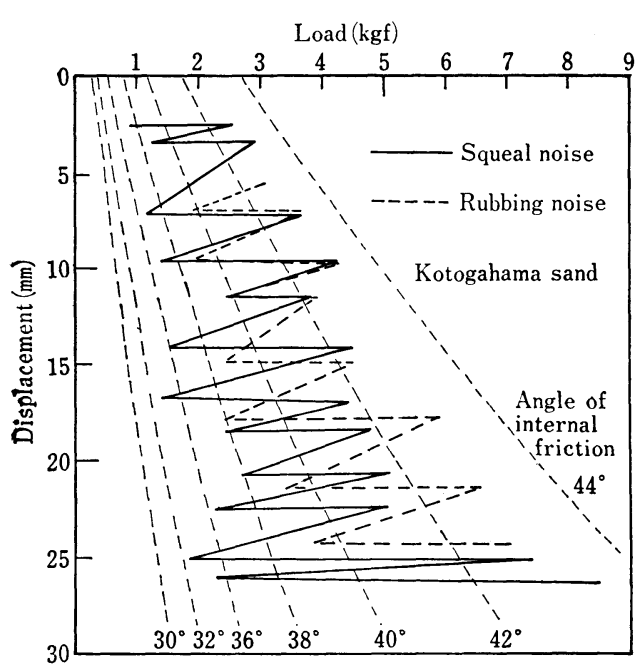

Fig. 19 Penetration characteristic curves for radiated and nonradiated harmonic sound of the singing sand.

が材質の影響を受け变化すること（Fig. 10）からその可 能性は低いと考元る。

このように鳴き砂に护ける音の発生機構は一般的な二 つの固体の摩擦接触により発生する音のそれとは異なる が粉体層の摩擦係数の速度特性にもとづいて発生する音 であり粉体層に拈ける摩擦音である。また中井ら ${ }^{12}$ は二 つの固体の摩擦接触による摩擦音を検討してこれをうす 永音 (Rubbing noise) と鳴き音 (Squeal noise) とに 分類しているが，粉体層においてもその摩擦特性により こす礼音（ケイ砂(d)の場合）と調和音を発生する鳴き音 （鳴き砂の場合）とが発生することが分った。

貫入棒の直径および貫入速度の影響 : Fig.17, 18 は 発生音の性質におよぼす貫入棒の直径および貫入速度の 影響を示している。貫入棒の直径が大きくなるにつれ発 生音の周波数が低下し，貫入速度の増大とともに高くな る傾向がある。貫入棒の絽固有振動数はその直径に無関 係であるために直径が増大するにつれ摩擦力が大きくな り Stick-Slip 摩擦にもとづく貫入抵抗力のパルスの回 数拉よびパルスの大きさが低下するものと考える。実際 に貫入試験において貫入板の直径を大きくするとすべり の回数は減少する ${ }^{5 !}$ 。また貫入速度が増大すると逆にパ
ルス状に作用する貫入抵抗力の作用回数が增しパルスの 大きさも大きくなるものと考兄られる。ただし Fig.18 (b)のように貫入速度の変化が小さい場合には逆に貫入速 度の增大により見掛けの $\phi_{s}, \Delta \phi$ が大きくなるために周 波数が低下することがある。このように前節で推定した 発音機構にもとついてて発音条件と発生音の性質との関係 を説明することができる。

鳴き音の発生条件 : 鳴き砂に貫入棒を貫入させても鳴 き音を発生する場合としない場合がある。これは貫入棒 にある大きさ以上のパルス状の貫入抵抗力が作用する必 要があるからである。そこで貫入棒の重量をゆっくりと 増加させて貫入速度を増大し鳴き音を発生した時とその 直前の鳴き音を発生しない時の貫入過程曲線を求めて Fig. 19 に示した。なお粉体層に作用する荷重は(1)式を 用いて貫入棒の加速度波形から求めた。また図中の点線 で示す支持力曲線は(3)式による計算值である。鳴き音を 発生する摩擦角の条件は試験条件によって異なるが本装 置 (貫入棒木製) では $\phi_{s} \doteqdot 43^{\circ}, \phi_{d} \doteqdot 37^{\circ}, \Delta \phi \doteqdot 6^{\circ}$ で あり鳴き音を発生しない場合の $\Delta \phi$ は約 $4^{\circ}$ であった。

\section{6. 結 言}

容器内に充てんした鳴き砂粒子層からの鳴き音の発生 機構について実験的に検討した結果次の結論を得た。

(1)鳴き砂はその貫入過程曲線が規則的な階段状の曲線 を示し顕著な Stick-Slip 摩擦を示す。この Stick-Slip 摩擦が音を発生する原因であり，鳴き砂を貫入棒で発音 させた場合の音の発生機構は鳴き砂の Stick-Slip 運動 にもとづいて生じるパルス状の貫入抵抗力が貫入棒に連 続的に作用して貫入棒の縦振動を励振することにより放 射されるものである。

(2)したがって鳴き砂粒子層部分を真空下においても明 りょらな調和音を系外に放射する。すなわちこの発音方 法による鳴き音は粒子の摩擦振動や粒子層空吵内の空気 の噴出および粒子層の振動にもとづいて発生する音では ない。

(3)鳴き砂の発生音は一般的な固体摩擦音とその発生機 構が異なるが粒子層の摩擦現象にもとづいて発生する摩 擦音であり, 粒子層の摩擦音の場合にも摩擦係数の速度 特性に関係してこすす音と鳴き音とが発生する。鳴き砂 粒子層は鳴き音を発生する曲型的な粒子群である。

\section{使 用 記 号}

\section{$D_{p} \quad$ : 貫入板の直径 \\ $H \quad$ : 粉体層表面からの貫入板の貫入距離 \\ $N_{q}$ : 支持力俰数 (貫入深さについて) \\ $N_{r}$ : 支持力俰数 (用性域について)}

$[\mathrm{cm}]$

$[\mathrm{cm}]$

[-]

$[-]$
$P$

: 粉体層に作用する圧縮力

$P_{u} \quad$ : 粉体層の極限支持力

$W \quad:$ すべり面上の粉体層の重量

$\Delta W$ : 貫入によって増加したすべり面上の重量増加 $\left[\mathrm{g} / \mathrm{cm}^{2}\right]$

Vol. 18 No. 5 (1981) 
$\boldsymbol{d}_{q}, \boldsymbol{d}_{r}$ : 支持力に対する貫入深さの影響を考慮する係数 $\quad[-]$

$g \quad:$ 重力加速度

$m$ : 貫入棒の重量

$\alpha \quad$ : 貫入棒の加速度 $\left[\mathrm{cm} / \mathrm{s}^{2}\right]$

[g]

$\left[\mathrm{cm} / \mathrm{s}^{2}\right]$ $\phi_{d} \quad$ : 粉体層の動摩擦角

$\phi_{s} \quad:$ 粉体層の静止摩擦角

$\Delta \phi \quad$ : 静止摩擦角之動摩擦角の差 $\left(\phi_{s}-\phi_{d}\right)$

$\rho_{B} \quad:$ 嵩密度

\title{
Literature cited
}

1) Akai, K.: Tsuchi no Shijiryoku to Chinka P 18 Sankaido, Tokyo (1964)

2) Bolton, H.C.: Nature, 42, [1093] 568 (1890)

3) Carus, Wilson C, : Nature, 43, [1098] 30 (1890)

4) Hashimoto, M.: Chigaku Kenkyu, 21, [6] 157-163 (1970)

5) Hidaka, J. and S. Miwa: Kagaku Kogaku Ronbunsyū, 7, [2] (1981), to be published

6) John, F. Lindsay: Geol. Soc. Am. Bull., 87, [3] 463473 (1976)
7) Kurihara, K.: Ōyō-Butsuri, 6, [4] 18-20 (1937)

8) Miwa, S. and J. Hidaka: Funtai to Kogyo, 10, [9] 26-30 (1978)

9) Miwa, S., T. Wakita and M. Toda: Funtai Kogaku Kenkyukaishi, 10, [7] 379-385 (1973)

10) Nishiyama, K.: Kagaku no jikken, 20, [4] 329-336. (1978)

11) Bagnold, R.A.: Proc. Roy. Soc., A295, 219-232(1966)

12) Yokoi, M. and M. Nakai: Nihon Kikaigakkai Ronbunsyū, 45, [391c] 346 (1979)

\section{Authors' Abstract}

\author{
Generating Mechanism of Harmonic Sound from Singing Sand \\ by \\ Jusuke HIDAKA and Shigeo MIWA \\ (Dept. of Chem. Eng., Doshisha Univ., Kyoto, Japan 602)
}

The mechanism causing the generation of harmonic sound from singing sand into which a rod penetrates is investigated experimentally. Stick-slip behavior distinctly occurs on compression flow of the singing sand, which is the reason for generation of the harmonic sound. The stick-slip friction characteristic of a singing sand is measured with a penetration test for a packed bed of particles.

The relationship between material of the penetrating rod, the stick-slip friction characteristic of the singing sand and the nature of the sound from the singing sand are discussed. The mechanism by which the harmonic sound from the singing sand is generated be explained as fllows: When the rod is penetrated into a packed bed of the singing sand, the impulsive force of resistnce to penetration of the rod which occurs from the stick-slip friction acts on the penetrating rod. Therefore, longitudinal vibration of the rod is excited, and the harmonic sound is radiated to in atmosphere. The sound generation based on the friction of particles can be classified into a squeal noise and a rubbing noise related to the friction characteristic of the particles. 